\title{
Post-Settlement Processes Determining the Features of Bivalve Assemblages in Tidal Flats
}

\author{
Hideo SEKIGUCHI, MiCHITAKA UCHIDA and AKIHISA SAKAI \\ Department of Fisheries, Faculty of Bioresources, Mie University
}

\begin{abstract}
SEKIGUCHI, Hideo, Michitaka UCHIDA and AKIHISA SAKAI (Faculty of Bioresources, Mie University). 1995. Post-settlement Processes Determining the Features of Bivalve Assemblages in Tidal Flats. Benthos Research, 49: 1-14.

The mouths of two rivers in Japan, the Ano and the Shitomo, are adjacent to each other but show a marked difference in their bivalve assemblages on the tidal flats. From the results of a four-year field investigation on the densities of larvae and recruitants of three dominant bivalves (Nuttallia olivacea, Ruditapes philippinarum, Musculista senhousia), we sought to see whether pre- or post-settlement processes are the important factors determining the features of the bivalve assemblages in each river. They were found to be determined basically by post-settlement processes. However, in some years, they were determined after larval recruitment $(>1.0 \mathrm{~mm}$ in shell length), and in other years immediately after the larvae had settled on the tidal flats or after the bivalves had reached a certain size but before larval recruitment.
\end{abstract}

Introduction

It has long been recognized that larval recruitment processes influence the population dynamics and community structure of marine benthic animals with a complex life cycle including planktonic and benthic life phases (UnderWOod \& Fairweather, 1989; GrosberG \& Levitan, 1992). However, little work has been done on larval recruitment processes in the ma-

Received April 22, 1994 : Accepted March 8, 1995 rine environment, probably due to the difficulty in identifying planktonic larvae (HoRIKosHI, 1978) and in examining their transport and/or dispersal (De Wolf, 1973; Roughgarden et al., 1988). Nonetheless, the role of larval recruitment in the population dynamics and community structure of marine benthic animals is the subject of active research today (GrosBerG, 1982; Yoshioka, 1982 ; Caffey, 1985 ; Gaines \& Roughgarden, 1985).

Similar studies on intertidal animals have indicated that their distribution and abundance, 
especially for barnacles, is determined mainly by post-settlement processes (e.g., competition for space, physical disturbance, predation) when the settlement rate is high, whereas it is determined by spatial and temporal variations in settlement when the settlement rate is low (GAines \& Roughgarden, 1985; Gaines et al., 1985; Connell, 1985). Unfortunately, little work has yet been done on larval recruitment in bivalve assemblages. In a infaunal bivalve, Mulinia lateralis, rapid changes in abundance after larval settlement led to distribution patterns which, after one month, differed substantially from the larval settlement patterns (LUCKENBACH, 1984).

We have carried out a four-year investigation of larval recruitment processes in bivalve assemblages on the tidal flats of the Ano and Shitomo Rivers in Mie Prefecture, Japan. Previous studies done on the tidal flats of these rivers (SAKaI, 1992; Kimura \& SeKiguchi, 1993 a, b ; SEKIGUCHI, unpublished data) had suggested that the difference in their bivalve assemblages was remarkable even though the mouths of the rivers were adjacent to each other: two species (Ruditapes philippinarum, Musculista senhousia) are predominant in the Shitomo River, whereas Nuttallia olivacea is predominant in the Ano River. In order to study the mechanisms by which the features of the bivalve assemblages of these two rivers are determined, we first attempted to clarify whether pre- (e.g., larval supply, settlement) or post-settlement processes play an important role. Fortunately, it is now possible to identify to the specific level both the planktonic and settled larvae of bivalves common on subtidal and intertidal flats in Japan, according to XU (1983) and SAKAI \& SEKIGUCHI (1992).

\section{Materials and Methods}

\section{STUDY AREA}

The Ano and Shitomo Rivers, located in Tsu city, flow into the western part of Ise Bay along the Pacific coast of central Japan (Fig. 1). These rivers are small and short; the Ano River runs a distance of $27.9 \mathrm{~km}$ and passes through the lowlands of Tsu city, whereas the Shitomo River, with a length of $14.5 \mathrm{~km}$, passes through rice fields. Saline water is detectable from the river mouth to a weir $2.3 \mathrm{~km}$ upstream in the Ano River, and from the mouth to a point $5.5 \mathrm{~km}$ upstream in the Shitomo River (KImURA \& SEKIGUCHI, 1993b).

Despite the mouths of the two rivers being adjacent to each other, the sediment types of the tidal flats at the two river mouths are different. In general, the grain size of the sediment is smaller, and the silt-clay content is clearly higher in the Shitomo River than in the Ano River (Kimlra \& Sekiguchi, 1993 a, b).

\section{SAMPLING AND PROCESSING OF BIVALVES}

Sampling was done on the tidal flats of the Ano and Shitomo Rivers for four years from April, 1990, to December, 1993. For sampling of bivalves in the benthic phase on the tidal flats, we set up three sampling stations (Stns. A,C,D) on the Ano River tidal flat and four stations (Stns. $0,1,2,3$ ) on the Shitomo River tidal flat, although the sediment at two of the stations (Stns. 3,D) was always under water of some tens of centimeters depth even when the spring tide was out (Fig. 1). In addition to these sampling stations, we set up two stations (Stns. P, $\mathrm{P}^{\prime}$ ) for sampling planktonic larvae of bivalves in the mouths of the two rivers (Fig. 1).

Since we collected bivalves in a variety of pre- and post-settlement phases, i. e., planktonic larvae, settled bivalves, or small and large bivalves, various types of sampling gear were used in this study as described below. Settled bivalves were defined as settled individuals with shell lengths less than $0.3 \mathrm{~mm}$, because among the bivalves common on tidal flats in Japan, the shell length has been known to reach ca. 200-300 $\mu \mathrm{m}$ very shortly after planktonic larvae have settled on the bottom sediment (YoshidA, 1953; 


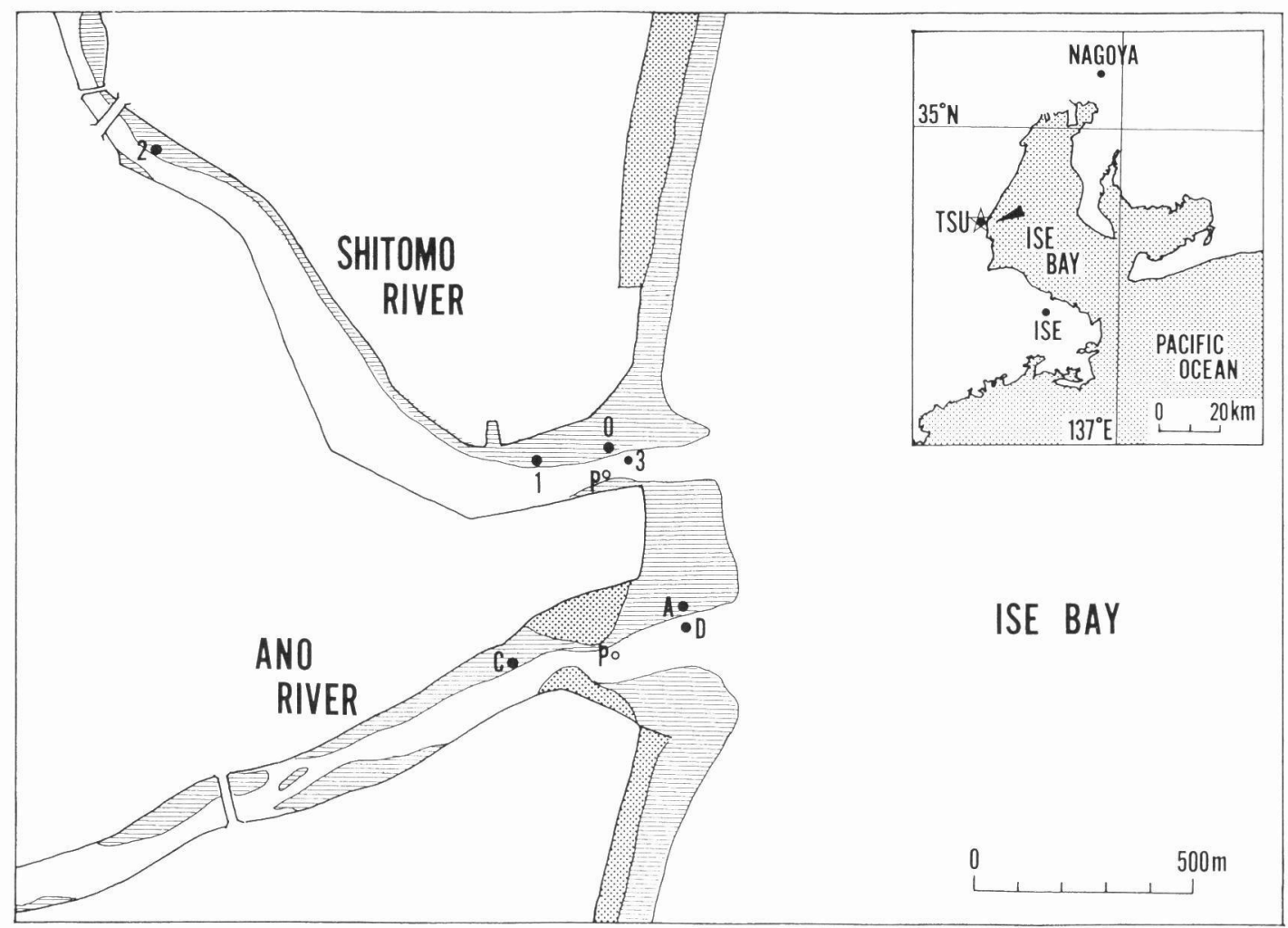

Fig. 1 Study area and location of sampling stations. Dotted areas: sediment exposed during the low water of spring tide; hatched areas: sediment in the intertidal zone; A,C,D and 0,1,2,3: sampling stations for bivalves; P: sampling stations for plankton.

Xu, 1983; SAKaI \& SeKiguchi, 1992). Small bivalves were defined as individuals with shell lengths ranging from $0.3 \mathrm{~mm}$ to $1.0 \mathrm{~mm}$, while large bivalves had shell lengths of $1.0 \mathrm{~mm}$ or more.

Furthermore, we defined 'recruitment' as reaching a shell length of $1.0 \mathrm{~mm}$ or more (i. e., large bivalves). Definitions of recruitment in marine organisms vary according to the taxon, but it is well known that higher mortality occurs shortly after larvae settle on the bottom sediment, followed by a relatively constant and low mortality (HoRIKoshi, 1978). Higher mortality shortly after larval settlement has also been confirmed for several species of bivalves (MUUs,
1973).

For sampling planktonc larvae of bivalves, we collected the larvae at Stns. P and P' once a week from February, 1991, to December, 1993. The samples were obtained by pumping $95 l$ of water from an intermediate depth $(1.0 \mathrm{~m})$ during the flood tide, in order to avoid surface freshwater, and then filtered with a $45 \mu \mathrm{m}$ mesh sieve. The samples were fixed immediately with $5 \%$ neutral formalin seawater. The temperature and salinity of the pumped-up water were monitored with a salinometer (Salt-Meter NS-3P). In the laboratory, all specimens of planktonic veliger larvae of bivalves (excluding D-type 
veligers because of the difficulty in identifying them to the specific level) were sorted using a suction device (see, Sakai \& Sekiguchi, 1990) under a dissecting microscope, identified to the specific level according to SAKAI and SeKIGUCHI (1992), and counted according to species under a microscope.

For sampling settled and small bivalves, we collected sediment at Stns. A,C,D and at Stns. 0,1,2,3 once a week from April, 1990, to December, 1993. According to studies done previously in our study area (SAKAI, 1992; SeKIGUCHI , unpublished data), settled and small bivalves were largely aggregated within the upper $1 \mathrm{~cm}$ of the sediment. Two sediment samples were obtained at each station during the ebb tide using a core sampler $(3.4 \mathrm{~cm}$ in diameter, $1.0 \mathrm{~cm}$ depth) for collecting surface sediment, and then filtered with a $125 \mu \mathrm{m}$ mesh sieve. The samples were fixed immediately with $5 \%$ neutral formalin dyed with Rose bengal to facilitate sorting the specimens of settled bivalves. In the laboratory, all specimens of bivalves were sorted using a suction device, identified to the specific level, and counted according to species under a dissecting microscope. Shell lengths of the specimens were measured to the nearest $1.0 \mu \mathrm{m}$. Specimens of settled and small bivalves were identified according to SAKAI \& Sekiguchi (1992).

For sampling large bivalves, we collected sediment at Stns. A,C,D and at Stns. 0,1,2,3 once a Month from April, 1990, to December, 1993. Two sediment samples were obtained at each station during the ebb tide using a core sampler $(15.5 \mathrm{~cm}$ in diameter, $20.0 \mathrm{~cm}$ depth), and then filtered with a $1.0 \mathrm{~mm}$ mesh sieve. The samples were fixed immediately with $5 \%$ neutral formalin. All specimens of bivalves were sorted, identified to the specific level, and counted according to species. Shell lengths of the specimens were measured to the nearest $0.1 \mathrm{~mm}$.

The bivalve assemblages were totally dominated by three species ( $N$. olivacea, $R$. philippinarum, and $M$. senhousia) as referred to later in detail. Based on the data for the abundance of the planktonic larvae, settled bivalves, and small and large bivalves of these three species, we tested for differences in the abundance of each species between all pairs of sampling stations and between the rivers by employing Wilcoxon's test using Bonferroni's inequality (SoKal \& ROHLF, 1973; Yamamura, 1993).

\section{Results}

Three species of bivalves ( $N$. olivacea, $R$. philippinarum, and $M$. senhousia) were predominant among the macrobenthos in this study, as observed previously (Kimura \& SEKIGUCHI, 1993 a,b), and therefore the seasonal and interannual variations in the abundance of these three species and their spatial distribution are described below. In a forthcoming paper we shall examine the population dynamics of the bivalves in our study area, based on cohort analysis of our data.

\section{Nuttalia olivacea}

PLANKTONIC LARVAE (Fig. $2 \mathrm{a}, \mathrm{b}$ ) : No significant difference in density was found between the rivers $(p<0.05)$. Seasonal variations in density were remarkable and corresponded to those of settled bivalves, the densities being much higher in the fall of 1991 and 1992. Interannual variations in density were notable, the density in 1991 reaching more than 50 inds. $/ 100 l$ in the two rivers, as compared with less than 10 inds. $/ 100 l$ in the other years.

SETTLED BIVALVES (Fig. 3 a) : In 1992 the density was clearly higher in the Ano River than in the Shitomo River, but in the other years the differences in density were not significant (Fig. 4). The density changed markedly with the season, being much higher from October to January and almost zero in other months during the four-year investigation. Interannual variations in density were also notable, reaching more than 20 inds. $/ \mathrm{cm}^{2}$ in the Ano River in winter, 1991.

SMALL BIVALVES (Fig. 3 b) : The density 

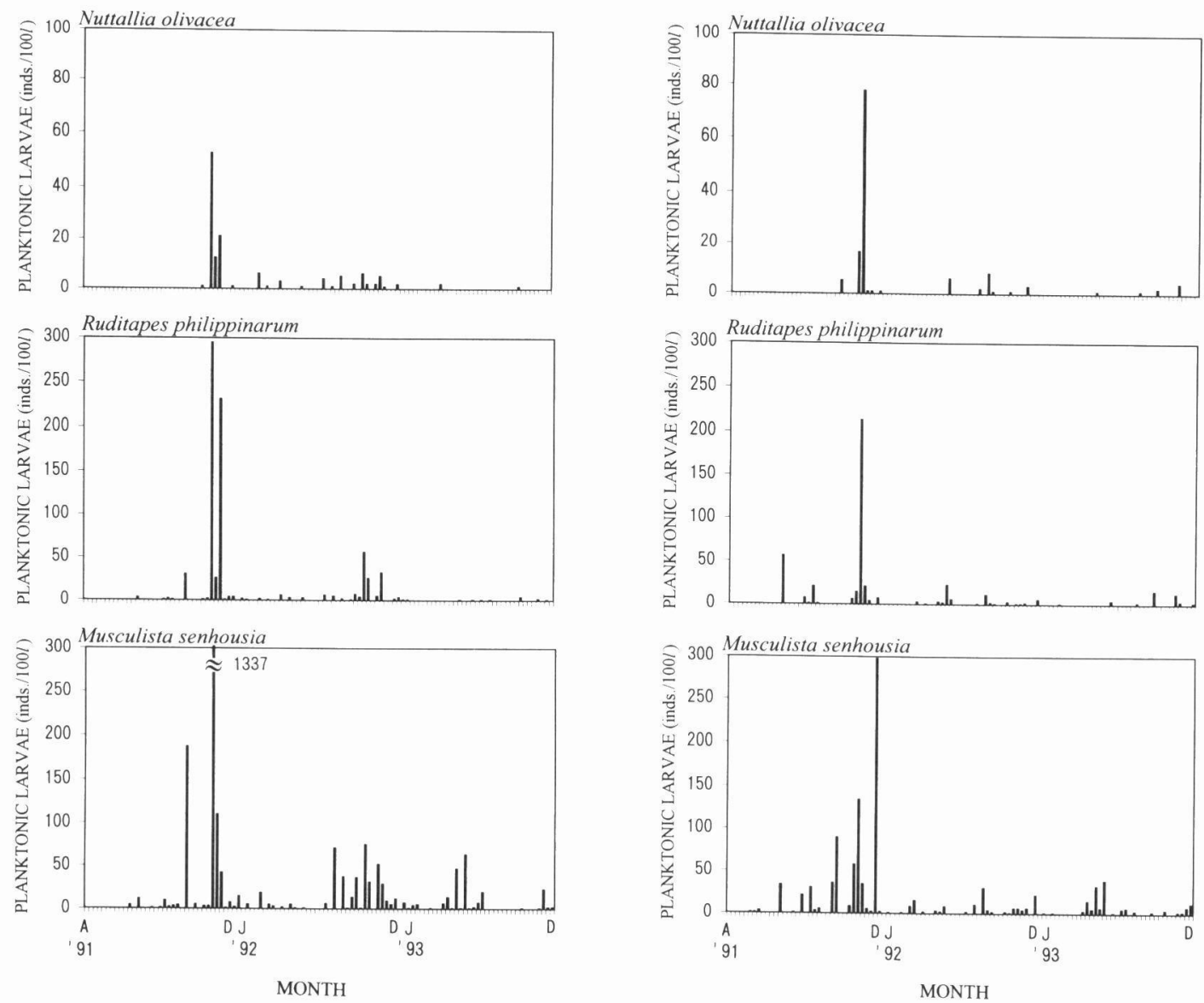

Fig. 2 Seasonal and interannual fluctuations in the densities of planktonic larvae of the three species of bivalves. a: the Ano River; b: the Shitomo River.

was higher in the Ano River than in the Shitomo River during the investigation period (Fig. 4). Seasonal variations in density were easily detected, but were not as remarkable as those of settled bivalves referred to above. Interannual variations in density were detected, the period with higher density (more than 0.5 inds. $/ \mathrm{cn}^{2}$ ) being much longer in 1992 than in the other year. The density exceeded 5.0 inds. $/ \mathrm{cm}^{2}$ in October, 1990, and January,1993, in the Ano River.

LARGE BIVALVES (Fig. 3 c) : The density was much higher in the Ano River than in the Shitomo River during the investigation period (Fig. 4). The bivalves were found intermittently in the Shitomo River, but at a very low density. In the Ano River the density (particularly at Stns. A,C) changed markedly with the season and drastically decreased every winter. Interannual variations in density were notable, the density reaching more than 10,000 inds. $/ \mathrm{m}^{2}$ in the Ano River from June to August, 1992. 
a

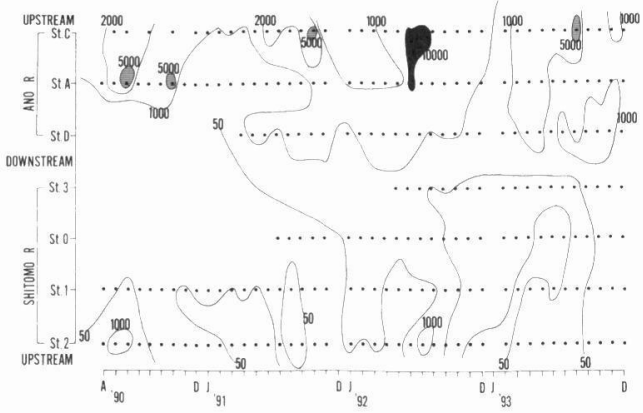

$\mathrm{b}$

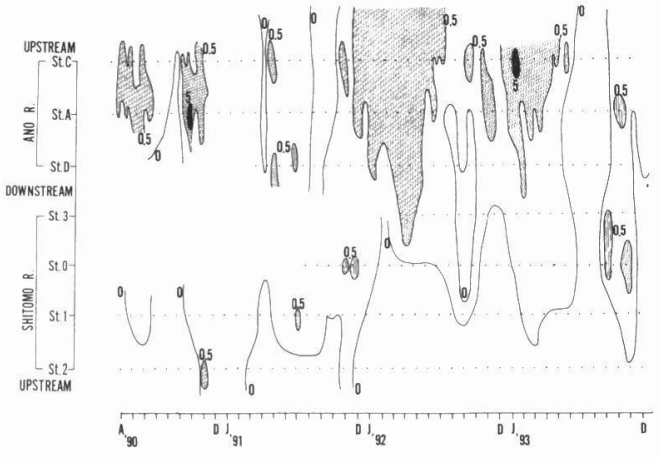

C

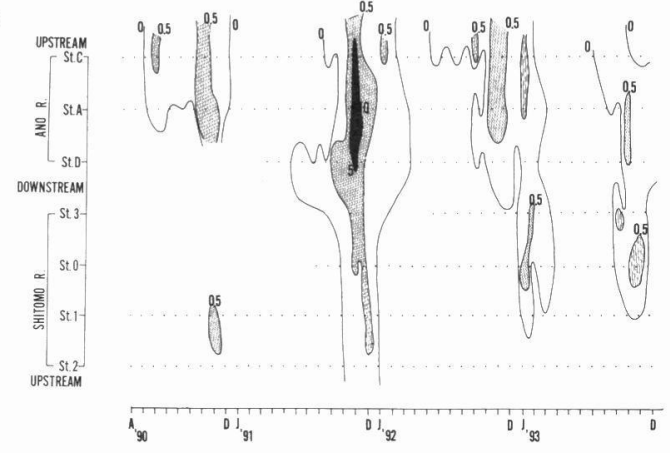

Nuttallia olivacea

\begin{tabular}{|c|c|c|}
\hline \\
\hline \multirow{4}{*}{$\begin{array}{l}\text { Large size } \\
\text { bivalves }\end{array}$} & $' 90$ & $A C 21$ \\
\hline & 91 & $\mathrm{C}>\underbrace{\mathrm{Al}} \mathrm{I}$ \\
\hline & '92 & $\begin{array}{llllll}C_{1}^{A} & A_{1} & 0 & & 1 & 2 \\
\end{array}$ \\
\hline & 93 & $C>A \begin{array}{lllllll}A & D & 0 & 1 & 2 & 3\end{array}$ \\
\hline \multirow{4}{*}{$\begin{array}{l}\text { Small size } \\
\text { bivalves }\end{array}$} & '90 & 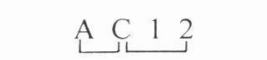 \\
\hline & '91 & $\begin{array}{lll}C A_{1} & 1 \\
\end{array}$ \\
\hline & '92 & $C A B>0$. \\
\hline & '93 & $C>A \begin{array}{lllllll}A & D & 0 & 1 & 2 & 3\end{array}$ \\
\hline \multirow{4}{*}{$\begin{array}{l}\text { Settled } \\
\text { bivalves }\end{array}$} & '90 & $\begin{array}{llll}A & C & 1 & 2\end{array}$ \\
\hline & '91 & A C 12 \\
\hline & '92 & $\begin{array}{lllllll}A & C & D & 0 & 1 & 2\end{array}$ \\
\hline & '93 & $\begin{array}{lllllll}A & C & D & 0 & 1 & 2 & 3 \\
\end{array}$ \\
\hline
\end{tabular}

Bonferroni adjustment multiple comparison $\mathrm{P}<0.05$ Bars indicate not significant.

Fig. 4 Difference and no difference in densities of Nuttallia olivacea among sampling stations. Letters: stations in the Ano River; numbers: stations in the Shitomo River; >: significant difference between stations using Wilcoxon's test, $p<0.05$; underlining: differences not significant among stations.

Fig. 3 Spatial and temporal distributions of Nuttalia olivacea in the Ano and Shitomo Rivers. a: large bivalves; $b$ : small bivalves; c: settled bivalves. Dots indicate when samples were collected at each station. 
a

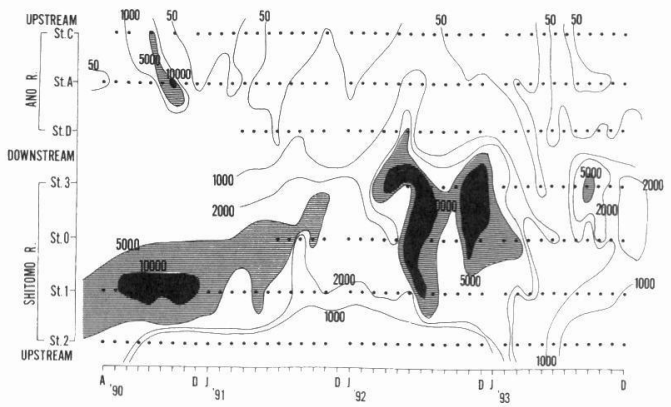

b

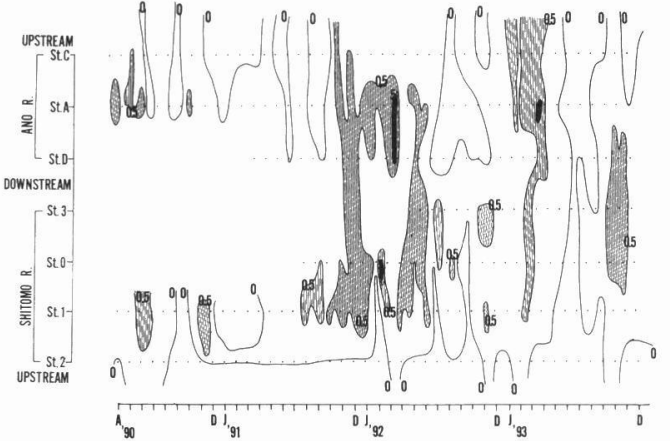

c

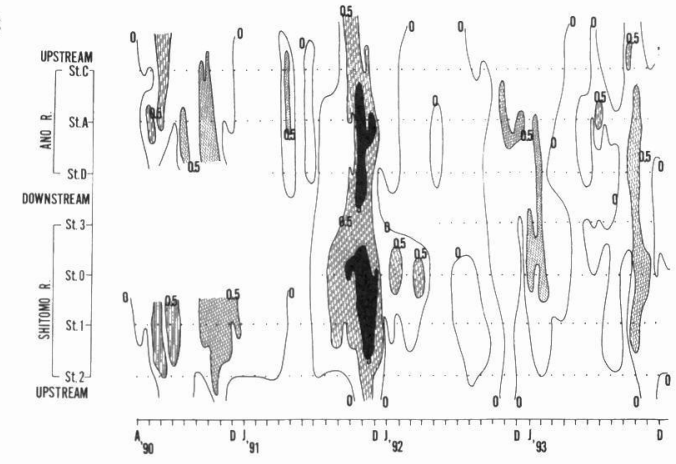

Fig. 5 Spatial and temporal distributions of Ruditapes philippinarum in the Ano and Shitomo Rivers. a: large bivalves; b: small bivalves; c: settled bivalves. Dots indicate when samples were collected at each station.

\section{Ruditapes philippinarum}

\begin{tabular}{|c|c|c|}
\hline \multirow{4}{*}{$\begin{array}{l}\text { Large } \\
\text { bivalves }\end{array}$} & '90 & $1>2 \mathrm{~A} \mathrm{C}$ \\
\hline & '91 & $1>2 \mathrm{ACC}$ \\
\hline & '92 & $0>12 \mathrm{ACD}$ \\
\hline & '93 & $03>12 \mathrm{ACC}$ \\
\hline \multirow{4}{*}{$\begin{array}{l}\text { Small } \\
\text { bivalves }\end{array}$} & '90 & $1 A \subseteq 2$ \\
\hline & '91 & $1>2 \mathrm{~A} \mathrm{C}$ \\
\hline & '92 & $0: \underbrace{0} \mathrm{~A} C \mathrm{D}{ }^{2}$ \\
\hline & '93 & 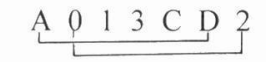 \\
\hline \multirow{4}{*}{$\begin{array}{l}\text { Settled } \\
\text { bivalves }\end{array}$} & '90 & $1>2 \mathrm{ACC}$ \\
\hline & '91 & $12 \mathrm{ACC}$ \\
\hline & '92 & $012 A C D$ \\
\hline & '93 & 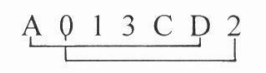 \\
\hline
\end{tabular}

Bonferroni adjustment multiple comparison: $\mathrm{P}<0.05$ Bars indicate not significant.

Fig. 6 Difference and no difference in densities of Ruditapes philippinarum among sampling stations. Letters: stations in the Ano River; numbers: stations in the Shitomo River; >: significant difference between stations using WiLcoxon's test, $p<0.05$; underlining: differences not significant among stations. 
a

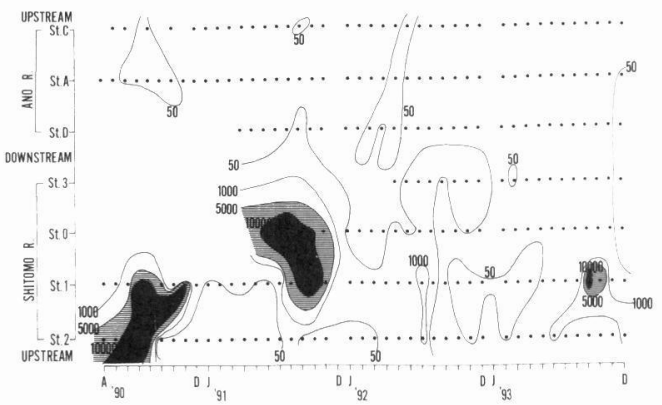

b

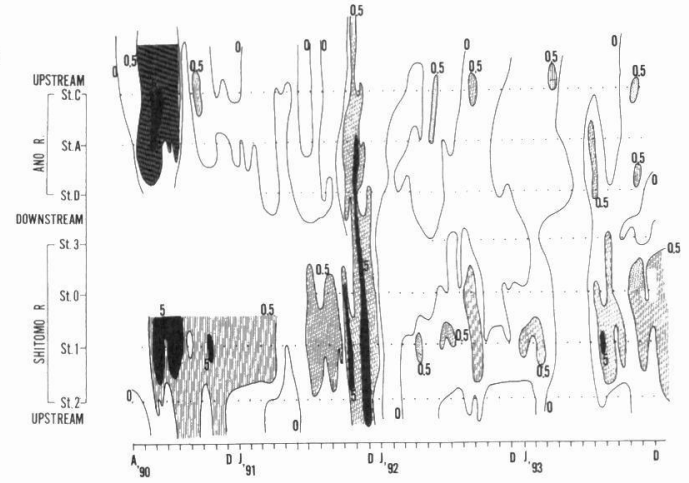

C

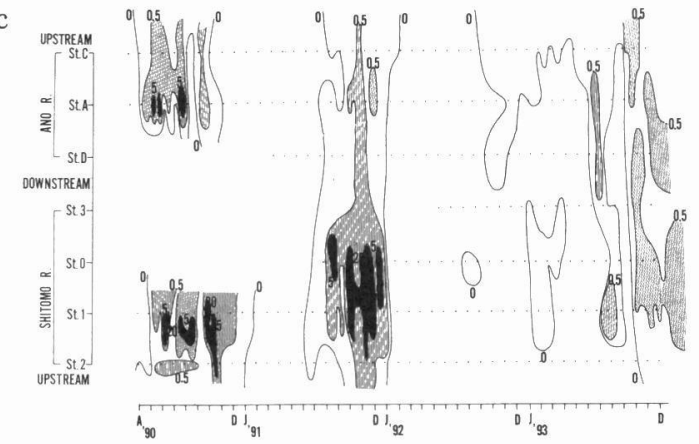

Fig. 7 Spatial and temporal distributions of Musculista senhousia in the Ano and Shitomo Rivers. a: large bivalves; b: small bivalves; c: settled bivalves. Dots indicate when samples were collected at each station.

\section{Musculista senhousia}

\begin{tabular}{|c|c|c|}
\hline \multirow{4}{*}{$\begin{array}{l}\text { Large size } \\
\text { bivalves }\end{array}$} & '90 & $12 \mathrm{~A} \mathrm{C}$ \\
\hline & '91 & $1>2 \mathrm{~A} \mathrm{C}$ \\
\hline & '92 & $\begin{array}{llllll}0 & 1 & 2 & A & C & D\end{array}$ \\
\hline & '93 & $\begin{array}{lllllll}0 & 1 & 2 & 3 & \mathrm{~A} & \mathrm{C} & \mathrm{D}\end{array}$ \\
\hline \multirow{4}{*}{$\begin{array}{l}\text { Small size } \\
\text { bivalves }\end{array}$} & '90 & $1>2 \mathrm{ACC}$ \\
\hline & '91 & $1>2 \mathrm{~A} \mathrm{C}$ \\
\hline & '92 & $102 \mathrm{~A} C \mathrm{D}$ \\
\hline & '93 & $1>023 \mathrm{~A} C \mathrm{D}$ \\
\hline \multirow{4}{*}{$\begin{array}{l}\text { Settled } \\
\text { bivalves }\end{array}$} & '90 & 1 A C 3 \\
\hline & '91 & $1>2 \mathrm{~A} \mathrm{C}$ \\
\hline & '92 & $012 A C D$ \\
\hline & '93 & $\begin{array}{llllllll}0 & 1 & 2 & 3 & \mathrm{~A} & \mathrm{C} & \mathrm{D}\end{array}$ \\
\hline
\end{tabular}

Bonferroni adjustment multiple comparison: $\mathrm{P}<0.05$ Bars indicate not significant

Fig. 8 Difference and no difference in densities of Musculista senhousia among sampling stations. Letters: stations in the Ano River; numbers: stations in the Shitomo River; >: significant difference between stations using WiLcoxon's test, $p<0.05$; underlining; differences not significant among stations. 


\section{Ruditapes philippinarum}

PLANKTONIC LARVAE (Fig. 2 a,b) : No significant difference in density was found between the rivers $(p<0.05)$. Seasonal variations in density were remarkable and corresponded to those of settled bivalves, the density being much higher in the fall of 1991 and 1992. Marked interannual variations in density were evident; the highest density in 1991 reached 295 inds./ $100 l$ in the Ano River and 215 inds. $/ 100 l$ in the Shitomo River.

SETTLED BIVALVES (Fig. 5 a) : No significant difference in density was found between the rivers except in 1990 (Fig. 4 ). However, the density at Stn. 2 was always lower than that at the other stations. The density changed with the season, tending to be higher every winter. Interannual variations in density were remarkable, and it reached more than 5.0 inds. $/ \mathrm{cm}^{2}$ in winter, 1991.

SMALL BIVALVES (Fig. 5 b) : Except 1991 the density did not differ between the rivers during the four-year investigation (Fig.6). However, the density at Stn. 2 was always lower than that at the other stations. Seasonal and interannual variations in density were detected, corresponding to less remarkable those of settled bivalves referred to above. Densities reached more than 5.0 inds. $/ \mathrm{cm}^{2}$ in winter, 1991.

LARGE BIVALVES (Fig. $5 \mathrm{c}$ ): The density was much higher in the Shitomo River than in the Ano River during the investigation period (Fig. 6). This was particularly so at the stations (Stns. 0.3) in the mouth of the Shitomo River, while the density was much lower at the upper station (Stn. 2). In the Shitomo River the density changed markedly with the season, tending to decrease every winter. Interannual variations in density were detected, and it exceeded 10,000 inds. $/ \mathrm{m}^{2}$ for relatively long periods in 1990 and 1992, but was very low in 1991 and 1993.

\section{Musculista senhousia}

PLANKTONIC LARVAE (Fig. 2 a,b) : No significant difference in density was found between the rivers $(p<0.05)$. The density changed markedly with the season, being much highest every year. Obvious interannual variations in density were also evident, and it reached a maximum of 1,336 inds. $/ 100 l$ in the Ano River and 297 inds. $/ 100 l$ in the Shitomo River in winter, 1991. The seasonal and interannual variations in density corresponded to those of settled bivalves.

SETTLED BIVALVES (Fig. 7 a): In 1991 the density was higher in the Shitomo River than in the Ano River. In the other years, differences in density between the rivers were not significant (Fig. 8 ). The density changed markedly with the season, tending to be higher in summer and winter but with fewer than 0.5 inds. $/ \mathrm{cm}^{2}$ in the other seasons. Interannual variations in density were easily detected, and the density reached a maximum of 5 inds. $/ \mathrm{cm}^{2}$ in 1990 in the Ano River, and in 1991 and 1992 in the Shitomo River.

SMALL BIVALVES (Fig. 7 b): The density was higher in the Shitomo River than in the Ano River (Fig. 8 ). Seasonal and interannual variations in density were evident, corresponding to those in settled bivalves, and the density reached more than 5.0 inds. $/ \mathrm{cm}^{2}$ in the fall of 1990 , winter of 1991, and summer of 1992

LARGE BIVALVES (Fig. $7 \mathrm{c}$ ): The density was markedly higher in the Shitomo River than in the Ano River, although by Wilcoxon's test $(p<0.05)$ the difference was not significant except in 1991 (Fig. 8 ). The bivalves were found intermittently in the Ano River, but at a very low density and were mostly absent. In the Shitomo River there was a marked change in density with the season, decreasing every winter. Interannual variations in density were notable, and it often exceeded 10,000 inds. $/ \mathrm{m}^{2}$ in 1991 and 1992.

\section{Discussion}

From the results of this study and previous investigations carried out in our study area (SaKai, 1992; Kimura \& Sekiguchi, 1993 a,b; Sekiguchi, unpublished data), there is known to 
Table 1 Seventeen alternative hypotheses that explain the steps by which the features of the bivalve assemblages of the Ano and Shitomo Rivers are established.

\begin{tabular}{ccccc}
\hline LARVAE & $\begin{array}{l}\text { SETTLED } \\
\text { BIVALVES }\end{array}$ & $\begin{array}{l}\text { SMALL } \\
\text { BIVALVES }\end{array}$ & $\begin{array}{l}\text { LARGE } \\
\text { BIVALVES }\end{array}$ & HYPOTHESIS \\
\hline $\mathrm{N}$ & - & - & $\mathrm{D}$ & $\mathrm{A}$ \\
$\mathrm{N}$ & $\mathrm{N}$ & $\mathrm{N}$ & $\mathrm{N}$ & $\mathrm{B}$ \\
$\mathrm{N}$ & $\mathrm{N}$ & $\mathrm{N}$ & $\mathrm{D}$ & $\mathrm{C}$ \\
$\mathrm{N}$ & $\mathrm{N}$ & $\mathrm{D}$ & $\mathrm{N}$ & $\mathrm{D}$ \\
$\mathrm{N}$ & $\mathrm{N}$ & $\mathrm{D}$ & $\mathrm{D}$ & $\mathrm{E}$ \\
$\mathrm{N}$ & $\mathrm{D}$ & $\mathrm{N}$ & $\mathrm{N}$ & $\mathrm{F}$ \\
$\mathrm{N}$ & $\mathrm{D}$ & $\mathrm{N}$ & $\mathrm{D}$ & $\mathrm{G}$ \\
$\mathrm{N}$ & $\mathrm{D}$ & $\mathrm{D}$ & $\mathrm{N}$ & $\mathrm{H}$ \\
$\mathrm{N}$ & $\mathrm{D}$ & $\mathrm{D}$ & $\mathrm{D}$ & $\mathrm{I}$ \\
$\mathrm{D}$ & $\mathrm{N}$ & $\mathrm{N}$ & $\mathrm{N}$ & $\mathrm{J}$ \\
$\mathrm{D}$ & $\mathrm{N}$ & $\mathrm{N}$ & $\mathrm{D}$ & $\mathrm{K}$ \\
$\mathrm{D}$ & $\mathrm{N}$ & $\mathrm{D}$ & $\mathrm{N}$ & $\mathrm{L}$ \\
$\mathrm{D}$ & $\mathrm{N}$ & $\mathrm{D}$ & $\mathrm{D}$ & $\mathrm{M}$ \\
$\mathrm{D}$ & $\mathrm{D}$ & $\mathrm{N}$ & $\mathrm{N}$ & $\mathrm{N}$ \\
$\mathrm{D}$ & $\mathrm{D}$ & $\mathrm{N}$ & $\mathrm{D}$ & $\mathrm{O}$ \\
$\mathrm{D}$ & $\mathrm{D}$ & $\mathrm{D}$ & $\mathrm{N}$ & $\mathrm{P}$ \\
$\mathrm{D}$ & $\mathrm{D}$ & $\mathrm{D}$ & $\mathrm{D}$ & $\mathrm{Q}$ \\
\hline
\end{tabular}

*) $\mathrm{N}$ indicates no difference in densities between the rivers, while $\mathrm{D}$ indicates a difference between the rivers. Dotted lines indicate that either a difference or no difference between the rivers may apply. See text for further details.

be a marked contrast in the bivalve assemblages between the Ano and Shitomo Rivers despite the fact that the river mouths are adjacent to each other: two species ( $R$. philippinarum, $M$. senhousia) were predominntly abundant in the Shitomo River, while $N$. olivacea was abundant only in the Ano River. In order to clarify the mechanisms that determine the features of the bivalve assemblages in the two rivers, it is first necessary to determine whether pre- or post-settlement processes play an important role.

On the basis of the differences or lack of difference between the two rivers in the densities of planktonic larvae, settled bivalves, and small and large bivalves, seventeen alternative hypotheses (A-Q) can be derived (Table 1) for explaining the steps, but not the mechanisms, by which the features of the bivalve assemlages are established.
In this study, the densities of planktonic larvae of the three species did not differ between the rivers, while those of large bivalves were significantly different (Figs. 3,6,8). However, with regard to settled and small bivalves, densities were significantly different between the rivers in some years but not in others. Therefore, the present results indicate that post-settlement processes, i.e., those operating after larval recruitment, are important in determining the features of the bivalve assemblages in the two rivers. If one accepts that five (A,C,E,G,I) of the seventeen hypotheses can not be ruled out, then, according to either a difference or lack of difference in the densities of settled bivalves between the rivers, these hypotheses can be classified into two groups: A,C,E and A,G,I.

HYPOTHESIS A: Regardless of the presence or absence of a difference in the densities of settled and small bivalves between the rivers, a 
difference in the densities of large bivalves becomes established between the rivers; i.e., a difference in the densities of large bivalves would be determined after larval recruitment.

HYPOTHESIS C: A difference in the densities of large bivalves is established between the rivers, although the densities of settled and small bivalves do not differ between them; i.e., the difference in the densities of large bivalves is determined after larval recruitment.

HYPOTHESIS E: Differences in the densities of small and large bivalves are established between the rivers, although those of settled bivalves do not differ; i.e., a difference in the densitie of large bivalves is determined after the bivalves reach a certain size (shell length between $0.5 \mathrm{~mm}$ and $1.0 \mathrm{~mm}$ ).

HYPOTHESIS G: Differences in the densities of settled and large bivalves are established between the rivers, although those of small bivalves do not differ; i.e., a difference in the densities of large bivalves would be determined after larval recruitment.

HYPOTHESIS I: Differences in the densities of settled, small and large bivalves are established between the rivers; i.e., a difference in the densities of large bivalves would be determined after the larvae had settled on the tidal flats.

As mentioned previously, the densities of planktonic larvae of the three species of bivalves did not differ between the rivers, whereas those of large bivalves were significantly different. Thus, whether or not a difference existed for settled and small bivalves would depend on the sampling year. Accordingly, depending on species and sampling year, the above-mentioned five hypotheses $(A, C, E, G, I)$ can be selected as follows:

$\begin{array}{cccc}\text { sampling year } & \text { Nuttallia } & \text { Ruditapes } & \text { Musculista } \\ 1990 & \text { A, E } & \text { A, I } & \text { A, C } \\ 1991 & \text { A, C } & \text { A, C } & \text { A, I } \\ 1992 & \text { A, I } & \text { A, C } & \text { A, C } \\ 1993 & \text { A, C } & \text { A, C } & \text { A, C }\end{array}$

As indicated above, in order to explain the differences between the rivers in the densities of large bivalves, one would expect that hypothesis A, C, or E, probably hypothesis A or C, would be accepted. However, hypothesis $\mathrm{A}$ and $\mathrm{C}$ are in fact indistinguishable from each other. Then, in the cases of $R$. philippinarum in 1990 through 1992 and $M$. senhousia in 1991, one would accept hypothesis A or I, although the latter appears to be simpler and more suitable.

To summarize, in some years the features of the bivalve assemblages of the two rivers were determined after larval recruitment (hypothesis A or C), whereas in other years this occurred after the larvae had settled on the tidal flats or after the bivalves had reached a certain size (hypothesis $\mathrm{E}$ or I), although one would accept hypothesis A or C in most cases. From the data of Kimura \& Sekiguchi (1993 a), who studied the population dynamics of $M$. senhousia in our study area from 1987 to 1989 when the situation was different from that in usual years and also from the results of this study, densities for large individuals were higher in the Ano River than in the Shitomo River in 1987. Unfortunately, from our environmental data (KIMURA \& SEKIGUHI, 1993 a , b) it is not immediately apparent why different steps or mechanisms (which would determine the features of the bivalve assemblages in each river) exist according to sampling years and species, since data are available for only few cases.

In our study area where larval supply and settlement rates were high, the features of the bivalve assemblages would be determined through post-settlement processes, as discussed above. Recent work, although scanty, indicates that the distribution and abundance of intertidal organisms, especially barnacles, is determined mainly by post-settlement processes when the settlement rate is high, and by spatial and temporal variations in settlement when the settlement rate is low (GAINES \& ROUGHGARDEN, 1985; Gaines et al., 1985; ConNell, 1985). This may hold for our study area. 
What kinds of factors would be involved in the post-settlement processes (i. e., hypothesis A and C) ? To our knowledges, contrasting environmental conditions are largely detected in the sediment types of the tidal flats, where the grain size is smaller and the silt-clay content is higher in the Shitomo River than in the Ano River despite the close proximity of their mouths (Kimura \& SeKiguchi, 1993 a,b). This probably indicates that either of two processes operating among large bivalves would contribute to establishing the differences in the features of the bivalve assemblages between the rivers: first, differential site-specific mortality through postsettlement processes (intra- and inter-specific competition for space, physical disturbance and predation), and second, migration of large bivalves between the rivers.

In the infaunal bivalve Mulinia lateralis, rapid changes in abundance after larval settlement and differential site-specific mortality were reported to produce distribution patterns which, after one month, differed substantially from the larval settlement patterns (LUCKENBACH, 1984). However, little work has been done to clarify the role of differential site-specific mortality in the post-settlement processes of marine benthic animals. Accordingly, we intend to address this problem by carrying out field experiments in our study area in the near future.

I has long been recognized in the marine environment and in the laboratory that bivalves migrate and or disperse in response to tidal currents by floating in the water using drift threads in the case of young post-lrvae (SIGURDSSON et al., 1976; LANE et al., 1985) and also juveniles and adults (Wolf \& WolF, 1977; Hamada \& INO, 1954), and by digging into the sediment, as reported for juveniles and adults of $R$. philippinarum (SAI, 1963). Of the three species of filter-feeders examined here ( $N$. olivacea, $R$. philippinarum and $M$. senhousia), the former two are infaunal, while the last is epifaunal. In particular, M. senhousia often forms large colonies which almost completely enclose the individuals, and these bivalves are anchored in position by a well-developed byssus (KIMURA \& SEkiguchi, 1993 a). Thus, except for a time shortly after the larvae have settled on the sediment, migration and/or disperse is difficult for $M$. senhousia. Therefore, the role of such migration in the water or within the sediment has not yet been examined for two species ( $N$. olivacea, $R$. philippinarum) studied here.

\section{Acknowledgements}

We wish to express our sincere thanks to anonymus referees for their comments on the draft. Thanks are also extended to the students and staff of the Aquatic Ecology Laboratory, Mie University, for their assistance and cooperation in sampling.

\section{References}

CAFFey, H. M., 1985. Spatial and temporal variation in settlement and recruitment of intertidal barnacles. Ecol. Monogr., 55: 313332.

Connell, J. H., 1985. The consequences of variation in initial settlement vs. pot-settlement mortality in rocky intertidal communities. J. Exp. Mar. Biol. Ecol ., 93: 11-45.

DE Wolf, P., 1973. Ecological observations on the mechanisms of dispersal of barnacle larvae during planktonic life and settling. Netherlands J. Mar. Res ., 6: 1-129.

GAINES, S. and J. RoughGarden, 1985. Larval settlement rate: a leading determinant of structure in an ecological community of the marine intertidal zone. Proc. Natl. Acad. Sci. U.S.A., 82: 3707-3711.

Gaines, S., S. Brown and J. Roughgarden, 1985. Spatial variation in larval concentrations as a cause of spatial variation in settlement for the barnacle, Balanus glanula. Oecologia, 67: 267-272.

GrosBerG, P.K.,1982. Intertidal zonation of barnacles: the influence of planktonic zonation 
of larvae on vertical distribution of adults. Ecology, 63: 894-899.

Grosberg, P. K. and D. R. Levitan, 1992. For adults only ? Supply-side ecology and the history of larval biology. Trends. Ecol. Evol., 7: 130-133.

Hamada, S. and T. Ino, 1954. Studies on the movement of the Japanese hard clam, Meretrix meretrix lusoria (RoRding) - 1 . Histological studies on the mucus gland in relation to locomotion. Bull. Japan. Soc. Sci. Fish., 20: 1-3. (in Japanese)

HoRikoshi, M., 1978. Larval ecology and bioturbation. Monthly Mar. Sci. Suppl., 1: 81-99. (in Japanese)

Kimura, T. and H. Sekiguchi, 1993a. Some aspects of population dynamics. of a mytilid Musculista senhousia (Benson) on tidal flats. Benthos Res., 44: 29-40.

Kimura, T. and H. Sekiguchi, 1993 b. Distribution of benthic animals of tidal flats in the neighbouring two rivers. Bull. Fac. Bioresources, Mie Univ., 10: 165-174. (in Japanese)

Lane, D. J., A. R. Beamont and J. R. Hunter, 1985. Bysus drifting and the drifting threads of the young post-larval mussel Mytilus edulis. Mar. Biol., 84: 301-308.

LuckenbaCh, M., 1984. Settlement and early postsettlement survival in the recruitment of Mulinia lateralis (Bivalvia). Mar. Ecol. Prog. Ser., 17: 245-250.

MuUs, K., 1973. Settlement, growth and mortality of young bivalves in the Oresund. Ophelia, 12: 76-116.

Roughgarden, J., S. Gaines and H. Possingham, 1988. Recruitment dynamics in complex life cycles. Science, 241: 1460-1466.

SAI, S., 1963. Movement of a clam, Ruditapes philippinarum. Aquaculture (Japan), 11: 13-24. (in Japanese)

SAKAI, A., 1992. Larval recruitment processes in bivalve assemblages in tidal flats. Master Thesis, 74pp., Mie University. (in Japanese)

Sakai, A. and H. Sekiguchi, 1990. A simple method of examination on hinge apparatus in settled bivalves. Benthos Res., 39: 21-22. (in Japanese)

SaKai, A. and H. Sekiguchi, 1992. Identification of planktonic late-stage larval and settled bivalves in a tidal flat. Bull. Japan. Soc. Fish. Oceanogr., 56: 410-425. (in Japanese)

Sugurdsson, J. B., C. W. Titman and P. A. Davis, 1976. The dispersal of young postlarval bivalve molluscs by byssus threads. Nature, 262: 386-387.

SoKAL, R. and F. J. RoHLF, 1973. Introduction to Biometrics, Freeman \& Company, San Francisco.

Underwood, A. J. and P. G. Fairweather, 1989. Supply-side ecology and benthic marine assemblages. Trends. Ecol. Evol., 4: 16-20.

Wolf, W. J. and L. D. Wolf, 1977. Biomass and production of zoobenthos in the Grevelingen estuary, the netherands. Est. Coast. Mar. Sci., 5: 1-24.

Xu, C. R., 1983. Studies on the identification of larvae and juveniles of several bivalves, and their early life history. Ph. D. Thesis, $180 \mathrm{pp}$., The University of Tokyo. (in Japanese)

YamamuRA, K., 1993. On the choice of multiple comparison procedures. SHOKUBUTSU BOEKI, 8: 28-35. (in Japanese)

YoshidA, Y., 1953. Studies on larvae and young shells of industrial bivalves in Japan. $J$. Shimonoseki Coll. Fish., 3: 1-106. (in Japanese)

Yoshioka, P. M., 1982. Role of planktonic and benthic factors in the population dynamics of the bryozoan Membranipora membranacea. Ecology, 63: 457-468.

\section{和文要旨}

関口秀夫・内田径孝・酒井明久 潮汐干潟の二枚貝 群集を決定する後着底過程

河口が隣接しているにもかかわらず，2つの河川の それぞれの河口干潟の二枚貝類群集，とくにその主要 種は著しく異なっていた。これらの河口干潟の主要種 
3 種類（イソシジミガイ，アサリ，ホトトギスガイ） の浮遊幼生, 着底稚貝, 稚貝および稚貝大型個体の 4 年間にわたる調查結果をもとに, 両河川の河口干潟の 二枚貝類群集の特徵あるいは相違が幼生の着底以前に 決定されているのか, あるいは着底以降に決定されて いるのかを調べた。両河口干潟の二枚貝類群集の相 違は, 大体において, 幼生の着底以降の諸過程, 特に 大型個体（殼長 $1.0 \mathrm{~mm}$ 以上）に成長以降に生じていた。
しかし，年によっては，幼生の着底直後（款長 $0.3 \mathrm{~mm}$ 未満）に， あるいは稚貝（款長 $0.3 \mathrm{~mm}$ 以上， $1.0 \mathrm{~mm}$ 未満） の段階で,この相違が生ずることもあった。

HIDEO SEKIGUCHI

Faculty of Bioresources, Mie University 1515 Kamihama-cho, Tsu, Mie 514, Japan 